\title{
Pengaruh Pemberian Probiotik Terhadap Performa Ayam Petelur
}

\section{The Effect of Probiotic Supplements on Layer Performance}

\author{
Madi Hartono dan Tintin Kurtini
}

Jurusan Peternakan, Fakultas Pertanian, Universitas Lampung

Jln. Prof. Soemantri Brodjonegoro, No. 1 Bandar Lampung 35145

Telp. (0721) 704946, Fax. (0721)770347

\begin{abstract}
This study was conducted to determine the effect of supplements probiotic on layer performance (consumption and conversion ration, persentage hen day and egg weight). This research was held on 21 July-24 August 2014 in the CV. Varia Agung Jaya henhouse laying in the District of Seputih Mataram, Center of Lampung Regency. Local probiotic was made in Microbiology Laboratorium and Moleculer Biology Laboratorium, Faculty of MIPA, Lampung University. The study used completely randomized design with 3 treatments (P1: control ration, P2: control ration with local probiotic 3\%, and P3: control ration with comercial probiotic 3\%) and 6 replications. Data obtained was analyzed using analysis of variance at 5\% level and continued Duncan test at $5 \%$ level. Based on the results we can conclude: the effect of treatments significant $(P<0.05)$ on consumption and conversion ration, but no significant $(P>0.05)$ on percentage of hen day and egg weight. Control ration significantly $(P<0.05)$ with control ration with local probiotic $3 \%$ and control ration with comercial probiotic $3 \%$ on consumption and conversion ration, but no significant $(P>0.05)$ on supplement probiotic.
\end{abstract}

Keywords: probiotics, performance, layer

05-06-2014 : disetujui 23-10-2015

\section{LATAR BELAKANG}

Probiotik adalah mikroba hidup yang diberikan sebagai suplemen makanan dengan tujuan memperbaiki kesehatan dan perkembangan mikroba, Penggunaan probiotik di kalangan peternak ayam telah banyak dilakukan karena mempunyai berbagai fungsi, antara lain mampu meningkatkan pertumbuhan dan efisiensi pakan, mencegah radang usus dan diare, meningkatkan produksi telur dan memperbaiki kualitas telur.

Selama ini produk-produk probiotik untuk unggas kebanyakan diimpor dari luar negeri dengan harga yang relatif mahal sehingga diperlukan kemampuan memproduksi probiotik untuk kebutuhan dalam negeri. Sumardi dan Ekowati (2008) melakukan penelitian untuk menyeleksi bakteri dari saluran pencernaan ayam kampung sebagai probiotik unggul dan karakterisasi mikroflora normal yang prospektif dari saluran pencernaan ayam kampung. Dari hasil secara in vivo dan in vitro 

(pada broiler) ternyata diketahui bahwa mikroba probiotik tersebut dapat menurunkan populasi bakteri Escherichia coli dan Salmonella sp (Sumardi et al., 2010). Penelitian dilanjutkan Kurtini et al.. (2013) diperoleh formula probiotik "lokal" yang mengandung mikroba lengkap (Saccharomyces sp, Rhizopus sp, Mucor sp dan Bacillus sp. ) yang dikemas dalam media (ragi).

Saccharomyces sp adalah feed supplemen yang kaya vitamin, enzim-enzim, zat makanan lain seperti karbohidrat dan protein. Selain itu, pada dinding Saccharomyces sp terdapat Manan-OligiSacharida (MOS) yang berfungsi mengikat mycotoxin (Dawson (1993) dalam Dutta et al.. (2009). Jamur Rhizophus sp termasuk spesies heterofermentatif yang menggunakan jalur fosfoketolase sebagai jalur utama dari metabolisme glukosa (Moat dan Foster, 1988), sedangkan Mucor sp termasuk kapang yang menghasilkan enzim amilolitik (Ali, 2005). Bakteri Bacillus sp mampu meningkatkan daya cerna (Haetamin et al., 2008) dan mempunyai sifat dapat mengsekresikan enzim protease, lipase, dan amilase (Fardiaz, 1992).

Penggunaan probiotik pada ternak unggas dilaporkan dapat menurunkan aktivitas urease, suatu enzim yang bekerja menghidrolisis urea menjadi amonia sehingga pembentukan amonia menjadi berkurang atau bahkan hilang. Amonia adalah suatu bahan yang dapat menyebabkan keracunan pada ternak unggas (Yeo dan Kim, 1997). Penelitian Asli et al. (2007) tentang probiotik yeast S.cerevisiae yang dikombinasikan dengan vitamin $\mathrm{E}$ dan $\mathrm{C}$ membuktikan bahwa probiotik tersebut mampu meningkatkan daya tahan tubuh unggas. Pemberian bakteri Bacillus $s p$ memengaruhi anatomi usus dan mampu meningkatkan kualitas telur, terutama menaikkan kekentalan albumen (Kompiang, 2009) Penelitian Malik (2013) tentang penggunaan probiotik (1, 2, dan 3\%) dalam ransum pada layer menunjukkan bahwa penggunaan probiotik sampai $3 \%$, berpengaruh nyata terhadap konsumsi dan konversi ransum ayam petelur periode layer tetapi tidak berpengaruh nyata terhadap produksi telur dan berat telur. Penggunaan probiotik sampai 3\% memberikan nilai ekonomi yang menguntungkan dengan menurunnya nilai konversi ransum.

\section{METODE}

Penelitian dilakukan pada 21 Juli sampai 24 Agustus 2014 di Peternakan Ayam Petelur CV. Varia Agung Jaya, Desa Varia Agung, Kecamatan Seputih Mataram, Kabupaten Lampung Tengah. Pembuatan probiotik lokal dilakukan di Laboratorium Mikrobiologi dan Laboratorium Biologi Molekuler FMIPA, Universitas Lampung.

Pada penelitian ini probiotik lokal dan probiotik komersial langsung dicobakan pada layer umur 43 minggu, strain Isa Brown. Ayam yang digunakan sebanyak 36 ekor yang ditempatkan dalam cage dengan sistem kandang panggung yang terbuat dari bilah-bilah kayu. Masing-masing cage terdiri dari 2 ekor yang dipelihara secara intensif.

Penelitian menggunakan Rancangan Acak Lengkap dengan 3 perlakuan pemberian probiotik dalam ransum. Perlakuan terdiri dari: P0 (Ransum kontrol), P1 (Ransum kontrol $+3 \%$ probiotik lokal), dan P2 (Ransum kontrol $+3 \%$ probiotik komersial), dan ulangan sebanyak 6 kali. Semua data dianalisis sesuai dengan asumsi sidik ragam pada taraf nyata 5\%. Uji Duncan dilakukan, jika ada peubah yang nyata (Steel dan Torry, 1995). Peubah yang diamati adalah konsumsi ransum, konversi ransum, hen-day (\%) serta bobot telur (g).

Probiotik lokal dibuat dengan mencampurkan inokulum kamir (Saccharomyces sp.), kapang (Mucor sp. dan Rhizopus sp), dan Bacillus sp. Probiotik komersial yang digunakan adalah "Soluble 
Organic Green Culture ZS" adalah campuran probiotik (Saccharomyces cerevisiae, Lactobacillus acidophilus, Bacillus subtilis, dan Aspergillus oryzae) produk Han Poong Industry Co., LTD, Korea.

Ransum percobaan (ransum kontrol) menggunakan ransum yang digunakan di peternakan ayam petelur CV. Varia Agung Jaya. Formula ransum terdiri dari jagung kuning (50\%), bekatul (20\%), dan konsentrat layer (30\%) serta premix (1\%) dengan kandungan protein kasar sebesar 14\% dan energi metabolis $2.850 \mathrm{kkal} / \mathrm{kg}$. Ransum perlakuan adalah ransum kontrol ditambah dengan $3 \%$ probiotik (lokal dan komersial).

\section{HASIL DAN PEMBAHASAN}

\section{Pengaruh Perlakuan terhadap Performa Ayam}

Performa ayam meliputi konsumsi ransum, produksi telur (persentase hen-day/HD dan bobot telur), dan konversi ransum. Rata-rata performa layer disajikan pada Tabel 1.

\section{Konsumsi Ransum}

Secara statstik pengaruh pemberian probiotik terhadap konsumsi ransum menunjukkan perbedaan yang nyata $(\mathrm{P}<0,05)$, yaitu konsumsi ransum perlakuan kontrol $(768,16 \mathrm{~g} / \mathrm{ekor} / \mathrm{minggu})$ nyata lebih rendah daripada konsumsi ransum perlakuan dengan penambahan probiotik lokal sebanyak $3 \%$ (779,16 g/ekor/minggu) dan perlakuan ransum dengan penambahan probiotik komersial sebanyak $3 \%$ (773,49 g/ekor/minggu). Akan tetapi, perlakuan dengan penambahan probiotik berbeda tidak nyata $(\mathrm{P}>0.05)$.

Tabel 1. Pengaruh pemberian probiotik terhadap performa layer (rata-rata konsumsi ransum, HD, bobot telur dan konversi ransum)

\begin{tabular}{lccc}
\hline \multicolumn{1}{c}{ Peubah } & $\begin{array}{c}\text { Ransum } \\
\text { kontrol }\end{array}$ & $\begin{array}{c}\text { Ransum kontrol + } \\
\text { probiotik lokal (3\%) }\end{array}$ & $\begin{array}{c}\text { Ransum kontrol + } \\
\text { probiotik komersial (3\%) }\end{array}$ \\
\hline Konsumsi ransum (g/ekor/minggu) & $768,16^{\mathrm{a}}$ & $779,16^{\mathrm{b}}$ & $773,49^{\mathrm{b}}$ \\
Hen-day (\%) & 75,89 & 72,63 & 68,88 \\
Bobot telur (g/butir) & 61,60 & 59,95 & 59,25 \\
Konversi ransum & $1,78^{\mathrm{a}}$ & $1,86^{\mathrm{b}}$ & $1,86^{\mathrm{b}}$ \\
\hline
\end{tabular}

Keterangan: Huruf superskript pada baris yang sama menunjukkan perbedaan nyata $(\mathrm{P}>0.05)$ dengan uji Duncan

Konsumsi ransum yang berbeda $(\mathrm{P}<0,05)$ antara perlakuan kontrol dengan perlakuan penambahan probiotik (lokal dan komersial) sebanyak 3\% terjadi karena ransum kontrol lebih palatabel dibandingkan dengan ransum perlakuan penambahan probiotik. Ransum dengan penambahan probiotik lokal dan komersial sedikit berdebu karena bentuk fisik probiotik berupa tepung. Dengan demikian, ayam untuk memenuhi kebutuhan nutrisinya dengan jalan mengonsumsi ransum lebih banyak.

Konsumsi ransum perlakuan dengan penambahan probiotik (lokal dan komersial) sebnyak 3\% berbeda tidak nyata $(\mathrm{P}>0.05)$. Hal ini terjadi karena ayam yang mengonsumsi probiotik mengalami peningkatan mukus pada usus halus yang diproduksi oleh Saccharomyces sp. Fakta ini sesuai dengan Bummer dkk. (2010) bahwa pemberian produk dinding sel (mukus) dari S. cerevisiae dapat merangsang sel goblet pada usus halus untuk memproduksi mukus. Adanya peningkatan mukus pada usus ayam ini diduga menjadi penyebab penyerapan zat-zat makanan terganggu sehingga ayam akan mengkonsumsi ransum lebih banyak untuk memenuhi kebutuhan nutrisinya. Akan tetapi, kondisi ransum ini masih bisa ditolerir oleh ayam, hal ini terbukti dari produksi telur dalam hen day (\%) dan 


\section{Madi Hartono dan Tintin Kurtini: Pengaruh Pemberian Probiotik Terhadap Performa Ayam Petelur}

bobot telur antar perlakuan tidak berbeda nyata $(\mathrm{P}<0,05)$. Selain itu, konsumsi ransum rata-rata perlakuan kontrol $(109,72 \mathrm{~g} / \mathrm{ekor} / \mathrm{hari})$, perlakuan ransum dengan penambahan probiotik lokal sebanyak 3\% (111,31 g/ekor/hari), dan perlakuan ransum dengan penambahan probiotik komersial sebanyak 3\% (110,49 g/ekor/hari) tidak jauh berbeda dengan standar konsumsi strain Isa Brown yaitu $110 \mathrm{~g} / \mathrm{ekor} / \mathrm{hari}$.

\section{Produksi Telur (\% hen day)}

Secara statistik, pengaruh perlakuan terhadap produksi telur (\% hen day) tidak berbeda nyata ( $\mathrm{P}>0.05)$. Persentase hen day yang tidak berbeda ini diduga disebabkan oleh adanya aktivitas mikroba dari Bacillus sp, Saccharomyces sp, dan Mucor sp. Mikroba tersebut dapat menghasilkan berbagai enzim yang mampu merombak zat makanan seperti karbohidrat, lemak, dan protein menjadi senyawa yang lebih sederhana sehingga mudah diserap (Buckle et al., 1987). Kondisi ini pada gilirannya akan meningkatkan produksi telur. Hal ini terlihat pada masing-masing perlakuan, ransum yang diberikan hampir seluruhnya dikonsumsi ayam, sehingga zat nutrisi yang terkandung dalam ransum tersebut digunakan sepenuhnya untuk produksi telur.

Hen-day yang tidak berbeda ini, juga terjadi karena probiotik mampu meningkatkan kesehatan ayam. Hal ini terbukti dari frekuensi pernafasan masing-masing perlakuan berturut-turut $(73,33$; 69,54; dan 71,91 kali/menit), suhu shank $\left(38,83 ; 38,68\right.$; dan $\left.38,89^{\circ} \mathrm{C}\right)$ yang relatif sama dan normal. Hal ini sesuai dengan pendapat Yeo dan Kim (1997) bahwa penggunaan probiotik pada ternak unggas dapat menurunkan aktivitas urease, suatu enzim yang bekerja menghidrolisis urea menjadi ammonia sehingga pembentukan ammonia menjadi berkurang atau bahkan hilang. Amonia adalah suatu bahan yang dapat menyebabkan keracunan pada ternak unggas. Dengan berkurangnya amonia, kondisi fisiologis ayam menjadi lebih sehat dan sama maka ayam akan mampu berproduksi yang sama pula, meskipun konsumsi ransumnya berbeda. Persentase hen day masing-masing perlakuan yaitu $70,27 \%$; $69,16 \%$; dan $63,59 \%$.

\section{Bobot Telur (g/butir)}

Secara statistik, pengaruh perlakuan terhadap bobot telur berbeda tidak nyata $(\mathrm{P}>0.05)$, hal ini diduga karena peranan Bacillus sp dalam probiotik mampu meningkatkan daya cerna dan dapat mengsekresikan enzim protease dan lipase. Dengan demikian, protein dan lemak dari ransum dapat dicerna sebagai bahan pembentuk putih dan kuning telur. Akibatnya bobot telur yang dihasilkan relatif sama dengan perlakuan kontrol (tanpa probiotik).

Selain hal di atas, bobot telur yang tidak berbeda ini disebabkan oleh bobot ayam yang relatif sama. Bobot ayam dan bobot telur mempunyai korelasi positif, ayam dengan bobot yang lebih berat memproduksi telur lebih berat dibandingkan dengan ayam dengan bobot tubuh yang ringan (Kurtini dkk., 2014). Rata-rata bobot tubuh ayam perlakuan berturut-turut $1,75 \mathrm{~kg}, 1,72 \mathrm{~kg}$, dan $1,71 \mathrm{~kg}$, seiring dengan bobot telur rata-rata perlakuan yaitu $61,60 \mathrm{~g} / \mathrm{butir}, 59,95 \mathrm{~g} / \mathrm{butir}$, dan 59,25 g/butir. Hasil penelitian ini sesuai dengan penelitian Malik (2013) yang menunjukkan bahwa penggunaan probiotik $(1,2$, dan 3\%) dalam ransum layer memberikan pengaruh yang tidak nyata terhadap produksi dan bobot telur.

\section{Konversi Ransum}

Secara statistik pengaruh perlakuan terhadap konversi ransum berbeda nyata $(\mathrm{P}<0.05)$. Perlakuan ransum kontrol nyata $(\mathrm{P}<0.05)$ lebih rendah dibandingkan dengan perlakuan penggunaan 
probiotik, sedangkan antara perlakuan dengan penggunaan probiotik lokal dan komersial tidak berbeda nyata $(\mathrm{P}>0.05)$.

Konversi ransum merupakan perbandingan antara konsumsi ransum dengan bobot telur yang dihasilkan. Konversi ransum yang berbeda antara perlakuan kontrol dengan perlakuan yang menggunakan probiotik disebabkan oleh konsumsi ransum yang lebih banyak dan bobot telur yang relatif lebih besar sehingga konversi ransum yang dihasilkan lebih kecil. Demikian juga dengan perlakuan ransum yang menggunakan probiotik tidak berbeda nyata karena sejalan dengan jumlah ransum yang dikonsumsi dengan bobot nya. Hasil penelitian ini sejalan dengan Malik (2013) yang menunjukkan bahwa penggunaan probiotik $(1,2$, dan 3\%) dalam ransum layer memberikan pengaruh yang nyata terhadap konsumsi dan konversi ransum. Konversi ransum untuk masing-masing perlakuan berturut-turut yaitu $1,78,1,86$, dan 1,86 .

\section{KESIMPULAN}

1. Pengaruh perlakuan ransum (kontrol, ransum kontrol dengan probiotik lokal 3\%, dan ransum kontrol dengan probiotik komersial 3\%) menunjukkan perbedaan yang nyata $(\mathrm{P}<0.05)$ terhadap konsumsi dan konversi ransum,

2. Pengaruh perlakuan ransum (kontrol, ransum kontrol dengan probiotik lokal 3\%, ransum dengan penambahan probiotik komersial 3\%) tidak berbeda nyata $(\mathrm{P}>0.05)$ terhadap persentase hen day dan bobot telur,

3. Perlakuan ransum kontrol berbeda nyata $(\mathrm{P}<0.05)$ dengan ransum probiotik lokal $3 \%$ dan ransum dengan penambahan probiotik komersial 3\% terhadap konsumsi dan konversi ransum, namun tidak berbeda nyata $(\mathrm{P}>0.05)$ antar penambahan probiotik.

\section{SARAN}

Penelitian ini perlu dilanjutkan dengan menambahkan probiotik lokal dalam berbagai dosis pada layer terhadap gambaran darah, produksi dan kualitas telur ayam petelur fase produksi.

\section{DAFAR PUSTAKA}

Ali, A. 2005. Mikrobiologi Dasar. Jilid I. State University of Makasar Press. Makasar

Asli, M. M., S. A. Hosseini, H. Lorfollahian and F. Shariatmadari . 2007. Effect of Probiotic, Yeast, Vitamin E and Vitamin C supplements on performance and immune response of laying hen during high environment temperature. International Journal of Poultry Science. 6 (12): 895900. ISSN 1682-8356

Buckle, K. A., R. Edward, G. H. Fleet, and M. Wooton. 1987. Ilmu Pangan. Terjemahan: H. Purnomo dan Adoiono. UI Press. Jakarta

Dutta, T. K., S. S. Kundu, and M. Kumar. 2009. Potential of direct-fed-mikrobials on lactation performance in ruminant-acritical review. Livestock Research for Rural Development. 21 (10):219-227 
Fardiaz, S. 1992. Mikrobiologi Pangan. Depdikbud Dirjen Dikti. Institut Pertanian Bogor. Bogor

Haetamin, K., Abun, dan Y. Mulyani. 2008. Study Pembuatan Probiotik (Bacillus liecheniformis, Aspergillus niger, dan Saccharomyces cereviseae) sebagai feed Supplement serta Implikasinya terhadap Pertumbuhan Ikan Nila Merah. Laporan Penelitian. Fakultas Perikanan dan Ilmu Kelautan. Universitas Padjadjaran. Bandung

Kompiang, I. P. 2009. Pemamfaatan mikroorganisme sebagai probiotik untuk meningkatkan produksi ternak unggas di Indonesia. Jurnal Pengembangan Inovasi Pertanian 2 (3): 117—191

Kurtini, T., D. Septinova, dan K. Nova. 2014. Produksi Ternak Unggas. Penerbit Anugrah Utama Raharja. Bandar Lampung

Malik, A. 2013. Pengaruh Penggunaan Probiotik Pada Ransum Terhadap Produktivitas dan Nilai Ekonomi Ayam petelur Periode Layer. Universitas Muhammadiyah. Malang. http:// pet Umum.ac.id/en/umm-news-2618,. Diakses 31 Mei 2013

Moat, A. G. and J. W. Foster. 1988. Microbial Physiology. John Wiley and Sons. New York

Steel, R. G. D. dan J. H. Torry. 1993. Prinsip dan Prosedur Statistika. Gramedia Pustaka Utama. Jakarta

Sumardi dan C. N. Ekowati. 2008. Isolasi dan Karakterisasi Flora Normal Saluran Gastrointestinal Ayam Kampung (Gallus domesticus) untuk Probiotik. Makalah disajikan pada seminar dan Rapat Tahunan (SEMIRATA) Badan Kerjasama PTN Wilayah Barat Bidang Ilmu MIPA di Universitas Bengkulu. 13-14 Mei 2008

Sumardi, M. Hartono, dan K. Handayani. 2010. Pengaruh Pemberian Biakan Bacillus sp terhadap Pertumbuhan Salmonella dan Escherichia coli pada Broiler. Prosiding Seminar Nasional Sains dan Teknologi-III. Unila . Bandar Lampung. 18-19 Oktober 2010. ISBN 978-979$8510-20-5$

Yeo, J. and K.I. Kim. 1997. Effect of feedening diets containing an antibiotic, probiotic, or yucca extract on growth and intestinal urease activity in broiler chick. Poultry Science 76:381-385 